ANNA SYLWESTRZAK

\title{
ZARZĄD DOCHODAMI Z MAJĄTKU DZIECKA
}

\section{WPROWADZENIE}

Stopniowy wzrost zamożności polskiego społeczeństwa sprawia, że reguły zarządu dochodami z majątku dziecka nabierają z biegiem czasu coraz większego znaczenia. Sytuacja, w której majątek dziecka przynosi dochody, podlega specyficznemu, złożonemu reżimowi zarządu. W odniesieniu do dochodów znajdują bowiem zastosowanie unormowania szczególne, wyłączające niektóre ogólne reguły zarządu majątkiem dziecka. Pośród nich kluczowa rolę odgrywa art. 103 k.r.o., zgodnie z którym czysty dochód z majątku dziecka powinien być przede wszystkim obracany na utrzymanie i wychowanie dziecka oraz jego rodzeństwa, które wychowuje się razem z nim, nadwyżka zaś na inne uzasadnione potrzeby rodziny. W literaturze stwierdza się, że przytoczony przepis jest wyrazem solidaryzmu rodzinnego ${ }^{1}$, ponieważ stanowi o egalitaryzmie wszystkich wychowujących się w rodzinie dzieci ${ }^{2}$ przez ustanowienie pomiędzy nimi zasady równej stopy życiowej, skoro uzyskany dochód powinien zostać przede wszystkim spożytkowany zarówno na zaspokojenie potrzeb dziecka, do którego należy majątek, jak i jego rodzeństwa. Unormowanie to realizuje cel wychowawczy, sprzyjając ukształtowaniu prawidłowej więzi osobistej między rodzeństwem oraz właściwej postawy etycznej dzieci, które to cele mogłyby ulec zaburzeniu w razie wystapienia znacznego uprzywilejowania jednego z dzieci.

Problematyka ta, podejmowana dotąd jedynie przy okazji analizy instytucji zarządu majątkiem dziecka, zasługuje na samodzielne, pogłębione opracowanie. Celem podjętych rozważań jest przedstawienie optymalnego kierunku zarządu majątkiem dziecka de lege lata, jak również analiza krytyczna obowiązujących unormowań, prowadząca do zaproponowania postulatów de lege ferenda.

1 Zob. K. Jagielski, Istota i treść władzy rodzicielskiej, „Studia Cywilistyczne” 1963, t. 3, s. 141; M. Nazar, w: J. Ignatowicz, M. Nazar, Prawo rodzinne, Warszawa 2016, s. 523.

2 J. Strzebinczyk, Prawo rodzinne, Warszawa 2016, s. 286. 


\section{PRZEZNACZENIE DOCHODÓW Z MAJĄTKU DZIECKA DE LEGE LATA}

Artykuł 103 k.r.o. wprowadza gradację celów, na które ma być przeznaczony dochód z majątku dziecka. Chodzi tu jednak tylko o dochód netto ${ }^{3}$ (verba legis: czysty dochód), co oznacza, że uzyskany przychód powinien być w pierwszej kolejności przeznaczany na pokrycie kosztów zarządu majątkiem dziecka, a dopiero uzyskana nadwyżka zostaje rozdysponowana zgodnie z dyrektywami zawartymi w art. 103 k.r.o. Ustawa nie precyzuje zakresu kosztów, które podlegaja w pierwszej kolejności zaspokojeniu z przychodu, za to w doktrynie wskazuje się, że są to ponoszone przez rodziców koszty zarządu majątkiem dziecka, z zastrzeżeniem jednak, że skoro zarząd sprawowany jest nieodpłatnie, niedopuszczalne byłoby odliczenie sobie przez nich wynagrodzenia ${ }^{4}$. Ratio legis tego unormowania tkwi w ustanowieniu przez ustawodawcę mechanizmu „samofinansowania” majątku dziecka, w ramach którego pasywa zostaja pokryte wytworzonymi aktywami ${ }^{5}$. Nie usuwa to jednak wątpliwości dotyczących niektórych szczegółowych kwestii, przykładowo: czy na liście pasywów podlegających pierwszoplanowemu finansowaniu można umieścić, poza nakładami koniecznymi, także szerzej zakrojone inwestycje, w tym ulepszenia zwiększające wartość majątku dziecka? Czy należy uwzględnić także koszty uzyskania i utrzymania tych składników majątku dziecka, które nie podlegaja zarządowi rodziców? ${ }^{6}$

Co do zakresu nakładów na majątek dziecka dokonywanych przez rodziców kosztem dochodów z tego majątku brak szczegółowej regulacji jawi się raczej jako jej zaleta, umożliwiająca elastyczność rozwiązań, przez dostosowanie zarządu majątkiem do sytuacji materialnej określonej rodziny. Tym sposobem w rodzinie dobrze sytuowanej rodzice mogliby przeznaczać osiagane dochody nie tylko na zachowanie majątku w dotychczasowym stanie, lecz nawet na dokonywanie ulepszeń, podczas gdy w rodzinach uboższych pozyskiwany dochód

${ }^{3}$ Przy zarządzie niezbyt złożonymi masami majątkowymi podkreśla się dopuszczalność jedynie przybliżonego ustalania tego dochodu, bacząc, by substancja majątku nie doznawała uszczerbku - T. Sokołowski, w: H. Dolecki, T. Sokołowski (red.), Kodeks rodzinny i opiekuńczy. Komentarz, Warszawa 2013, s. 714; E. Trybulska-Skoczelas, w: J. Wiercińskiego (red.), Kodeks rodzinny i opiekuńczy. Komentarz, Warszawa 2014, s. 715.

${ }^{4}$ Jednakże $\mathrm{w}$ razie powierzenia $\mathrm{w}$ uzasadnionym przypadku zarządu zarządcy, należy uwzględnić jego wynagrodzenie. Zob. T. Sokołowski, w: H. Dolecki, T. Sokołowski (red.), op. cit., s. 715 .

${ }^{5}$ Trafnie podkreśla się przy tym konieczność odróżnienia dochodu od wzrostu wartości składników majątku dziecka oraz korzystania z uzyskanych surogatów - M. Grochowski, w: K. Osajda (red.), Kodeks rodzinny i opiekuńczy. Komentarz. Przepisy wprowadzajace KRO, Warszawa 2017, s. 1273. Z kolei przy obliczaniu zysku nie uwzględnia się kosztów spadku wartości poszczególnych składników - tak trafnie G. Jędrejek, Kodeks rodzinny i opiekuńczy. Pokrewieństwo i powinowactwo. Komentarz do art. $61^{7}-144^{1}$, Warszawa 2014, s. 199.

${ }^{6}$ Wyłączenie zarządu rodziców może następować z mocy prawa (zarobek dziecka oraz przedmioty oddane mu do swobodnego użytku), z woli spadkodawcy lub darczyńcy (art. 102 k.r.o.) bądź z mocy orzeczenia sądu ograniczającego władzę rodzicielską w zakresie zarządu niektórymi składnikami majątkowymi. 
może okazać się niezbędny do utrzymania i wychowania dzieci, a wtedy jego wydatkowanie na inwestycje w majątku dziecka, kosztem obniżenia poziomu życia dzieci, byłoby niedopuszczalne. Przy rozstrzyganiu tych zagadnień należy kierować się ogólnymi dyrektywami określającymi sposób wykonywania władzy rodzicielskiej (zwłaszcza art. $95 \S 3$ k.r.o.). Podobnie gdy chodzi o kwestię pokrywania z dochodów z majątku dziecka kosztów utrzymania składników niepodlegających zarządowi rodziców, trudno o sformułowanie sztywnych reguł. Należy mieć także na uwadze, że poddanie poszczególnych części majątku dziecka zarządowi sprawowanemu przez różne podmioty nie prowadzi do powstania kilku niezależnych majątków; mamy bowiem nadal do czynienia z jednym majątkiem osobistym dziecka, który w podsumowaniu całościowym wykazuje określony bilans obciążeń i dochodów. Pominięcie takiej właśnie globalnej oceny mogłoby prowadzić do niezrównoważonej gospodarki majątkiem dziecka, prowadzącej do wytworzenia nadmiernego zadłużenia jednej części przy jednoczesnym przeinwestowaniu innej. Tym samym może pojawić się konieczność finansowania kosztów składników „wyłączonych” dochodami, jakie przynosi reszta majątku zarządzanego przez rodziców, zwłaszcza gdy te „wyłączone” składniki nie przynoszą dochodów (np. oddane dziecku do swobodnego użytku urządzenia elektroniczne czy sprzęt sportowy). Mechanizm „samofinansowania się" wyłaczonego składnika, polegający na prowadzeniu dla niego odrębnego bilansu pasywów i aktywów byłby usprawiedliwiony zwłaszcza wtedy, gdyby zarówno określony składnik majątku, jak również osiagane z niego dochody pozostawały pod zarządem podmiotu innego niż rodzice (np. zarządzane przez kuratora na skutek ograniczenia władzy rodzicielskiej obejmującego określony składnik majątkowy). Podobnie - ze względów wychowawczych - można by traktować koszty oraz dochody wynikajace z osiagania przez dziecko zarobku. Jednakże nawet i w tych sytuacjach nie byłoby wykluczone subsydiarne finansowanie zadłużenia z dochodów, jakie przynosi reszta majątku zarządzanego przez rodziców, w zakresie, w którym dochody osiągane ze składnika majątkowego wyłączonego z zarządu rodziców nie pokryły wszystkich związanych z nim kosztów ${ }^{7}$.

Wskazane w art. 103 k.r.o. cele, na które należy obracać czysty dochód z majątku dziecka, zostały poprzedzone określeniem „przede wszystkim”. Zakres odniesienia tego określenia odgrywa kluczową rolę przy oznaczeniu zakresu swobody rodziców przy rozporządzaniu dochodami. Otóż gdyby założyć, że określenie „przede wszystkim” odnosi się do wszystkich celów wskazanych w dalszej części przepisu, należałoby uznać, że ustawodawca wskazuje jedynie preferowane kierunki wydatkowania dochodu, które powinny mieć pierwszeństwo przed innymi możliwymi celami, niewymienionymi w treści unormowania. Kompetencje rodziców w tym ujęciu byłyby znacznie szersze niż według drugiej możliwej koncepcji, według której określenie „przede wszystkim” odnosi się tylko do pierwszego z wymienionych celów (potrzeb dziecka i jego ro-

7 Tym bardziej że przeznaczenie dochodów z pracy oraz z majatku dziecka zostało ukierunkowane w podobny sposób (art. 91 § 1 k.r.o.). Szerzej o tym A. Sylwestrzak, Obowiazki dziecka wobec rodziców, „Ruch Prawniczy, Ekonomiczny i Socjologiczny” 65, 2001, z. 3, s. 68. 
dzeństwa), ponieważ służy wskazaniu jego pierwszeństwa przed wymienionymi w dalszej części przepisu „innymi uzasadnionymi potrzebami rodziny”. W konsekwencji kompetencje rodziców do obracania dochodem ograniczałyby się do wyczerpująco oznaczonych celów, zachowujacych oznaczoną kolejność. Mając na uwadze dobro dziecka, które powinno determinować kierunek wykładni unormowań dotyczących władzy rodzicielskiej, należy opowiedzieć się za węższym zakresem uprawnień rodziców; rozszerzanie ich kompetencji służyłoby bowiem zaspokajaniu indywidualnych interesów pozostałych członków rodziny, a nie dobru dziecka ${ }^{8}$.

Przejdźmy do analizy pierwszorzędnego przeznaczenia czystego dochodu z majątku dziecka, którym jest utrzymanie i wychowanie dziecka oraz jego rodzeństwa, które razem z nim się wychowuje. Ponieważ ustawa nie dokonuje uprzywilejowania dziecka, któremu przysługuje majątek, przyjmuje się, że rozdysponowanie środków powinno nastapić proporcjonalnie do usprawiedliwionych potrzeb każdego z dzieci ${ }^{9}$. Krąg rodzeństwa, lege non distinguente, obejmuje zarówno rodzeństwo rodzone, jak i przyrodnie; zaliczyć należy tu także dzieci przysposobione w ramach przysposobienia pełnego. Krag ten został jednak ograniczony kryterium wychowywania się razem z dzieckiem, do którego należy majątek. W doktrynie zarysowała się rozbieżność co do zakresu tego ograniczenia. Według wąskiego ujęcia, przy wykładni pojęcia wspólnego wychowywania, o którym mowa w art. 103 k.r.o., należy sięgnąc do art. $58 \S 1$ zd. 3 k.r.o., co prowadzi do wniosku, że chodzi tu wyłącznie dzieci wychowywane przez te same osoby i w tym samym miejscu ${ }^{10}$. Natomiast według szerszego ujęcia możliwe byłoby również finansowanie potrzeb rodzeństwa zamieszkującego oddzielnie ${ }^{11}$, przy czym niektóre wypowiedzi akcentują wyjątkowość takiej sytuacji, która mogłoby uzasadniać tylko istnienie silnych więzi osobistych mających wpływ na wychowanie ${ }^{12}$. Najwięcej przemawia, jak się wydaje, za tym ostatnim kierunkiem. Umiejscowienie art. 103 k.r.o. pośród przepisów dotyczacych władzy rodzicielskiej (a nie w ramach obowiązku alimentacyjnego) świadczy o tym, że należy go postrzegać przede wszystkim przez pryzmat dobra dziecka, któremu przysługuje majątek, a dopiero w drugiej kolejności „przy okazji” - jako podstawę alimentowania reszty rodzeństwa. Dobro dziecka przemawia za wychowaniem go w materialnie egalitarnej grupie rodzeństwa, co sprzyja kształtowaniu się poczucia wspólności losów i wzmacnia pozytywne

8 Taki kierunek wykładni przyjmowany jest powszechnie w doktrynie, choć bez opatrywania go szerszym uzasadnieniem.

${ }^{9}$ H. Haak, Wtadza rodzicielska, Toruń 1995, s. 114-115; M. Grochowski, w: K. Osajda (red.), op. cit., s. 1273. Zdaniem T. Sokołowskiego, czysty dochód z majątku dziecka „przechodzi” w sfere pieczy nad osobą dziecka oraz jego rodzeństwa, co uzasadnia finansowanie z tych środków także potrzeb rodzeństwa - idem, w: H. Dolecki, T. Sokołowski (red.), op. cit., s. 714. Natomiast na gruncie art. $31 \S 2$ dekretu z 22 stycznia 1946 r. - Prawo rodzinne przyjmowano, że potrzeby rodzeństwa zaspokaja się dopiero wówczas, gdy zostaje nadwyżka po pokryciu potrzeb dziecka będącego właścicielem majątku - tak B. Dobrzański, Komentarz do Prawa rodzinnego, Łodź 1947, s. 73.

${ }^{10}$ H. Haak, op. cit., s. 114; G. Jędrejek, op. cit., s. 199. Kryterium jednej wspólnoty domowej stosuje bezwzględnie J. Gajda, Kodeks rodzinny i opiekuńczy. Komentarz, Warszawa 2000, s. 399.

${ }_{11}$ T. Sokołowski, Wtadza rodzicielska nad dorastajacym dzieckiem, Poznań 1987, s. 135.

${ }^{12}$ M. Grochowski, w: K. Osajda (red.), op. cit., s. 1273. 
relacje - i w tym należy upatrywać celu tego unormowania. Poza ten cel wykraczałoby dostarczanie środków osobom, z którymi nie łączy dziecka żadna faktyczna więź bądź też jest ona tak nikła, że nie ma wpływu na kształtowanie jego osobowości. W ramach oceny więzi rodzeństwa mającego oddzielne miejsca pobytu należałoby szczególnie uwypuklić istotne znaczenie zobiektywizowanego czynnika częstotliwości kontaktów rodzeństwa. Czynnik subiektywny, na który składa się więź emocjonalna, może bowiem na poszczególnych etapach rozwoju dzieci kształtować się różnie, oscylując między niechęcią a entuzjazmem; jego intensywność może również zależeć od różnicy wieku pomiędzy rodzeństwem, zatem choć podlega on uwzględnieniu, nie może jednak odgrywać znaczenia rozstrzygającego w sprawie finansowania potrzeb dzieci.

W świetle literalnego znaczenia przepisu do korzystania z dochodu jednego z dzieci kwalifikuje się tylko rodzeństwo małoletnie, co można wywieść z przesłanki wychowywania się rodzeństwa razem z dzieckiem; wychowanie jest bowiem jednym z atrybutów władzy rodzicielskiej ${ }^{13}$. Warto byłoby jednak wziąc pod rozwagę możliwość dokonania wykładni rozszerzającej, w drodze nawiązania do przesłanek obowiązu alimentacyjnego wobec dziecka, co prowadziłoby do objęcia korzyściami z dochodu małoletniego dziecka również rodzeństwa pełnoletniego, które nie osiagnęło jeszcze zdolności do samodzielnego utrzymania się, jeżeli nadal pozostaje we wspólnym gospodarstwie domowym. Osiagnięcie pełnoletności, jeżeli nie jest powiązane z jednoczesnym osiagnięciem samodzielności materialnej dzieci, nie zmienia bowiem istotnie z reguły faktycznych stosunków w rodzinie w płaszczyźnie materialnych odniesień.

Zagadnieniem problematycznym na gruncie art. 103 k.r.o. może okazać się kwestia dopuszczalności uwzględnienia potrzeb innych niż rodzeństwo dzieci wychowujących się wspólnie, np. dzieci spokrewnionych w linii bocznej w dalszym stopniu niż rodzeństwo oraz tzw. rodzeństwa socjologicznego, czyli wspólnie wychowujących się dzieci, które nie mają wspólnego przodka, co może mieć miejsce np. w przypadku przysposobienia niepełnego. Literalny sens przepisu wyklucza takie rozszerzenie; można też dodatkowo argumentować, że za ograniczeniem kręgu beneficjentów do rodzeństwa w znaczeniu prawnym przemawia istniejąca pomiędzy rodzeństwem wzajemność, znajdująca swój wyraz w trwającym całe życie stosunku alimentacyjnym (art. 128 k.r.o. i art. 134 k.r.o.), której to wzajemności brak w przypadku innych wspólnie wychowujących się dzieci. Rozumowanie takie w konkretnych okolicznościach mogłoby jednak doprowadzić do zaburzeń relacji osobistej dzieci pozostających we wspólnym gospodarstwie domowym. Wykładnia celowościowa nasuwa bowiem argument, że dobro dziecka będącego podmiotem majątku (rozumiane w aspekcie wychowawczym, edukacyjnym, a nie pojmowanym wyłącznie egoistycznie), może niekiedy przemawiać za „podzieleniem się” dochodem z innymi dziećmi będącymi członkami tego samego gospodarstwa domowego. Wydaje się zatem, że o tym, czy dzieci niebędące rodzeństwem moga uczestniczyć w konsumpcji dochodów na równi z uposażonym dzieckiem czy dopiero w dalszej kolejności (jako członek rodziny, której potrzeby będą zaspo-

${ }^{13}$ H. Haak, op. cit., s. 114. 
kajane z pozostałej nadwyżki), powinna rozstrzygać w konkretnych okolicznościach ocena dobra dziecka, którego dochodem się dysponuje.

Jeżeli po zaspokojeniu potrzeb uprawnionych dzieci pozostaje nadwyżka środków, mogą być one przeznaczone na inne uzasadnione potrzeby rodziny. Status nadwyżki nie jest jednak, jak się wydaje, stanem stałym, gdyż uzależniony jest od tego, czy w danym momencie istnieja potrzeby, które powinny być zaspokajane we wcześniejszej kolejności. Wygospodarowana nadwyżka, która nie została jeszcze skonsumowana, po pojawieniu się nowych potrzeb dzieci traci status nadwyżki i nie może być już przeznaczana na inne cele, lecz w pierwszej kolejności na zaspokojenie tych nowych priorytetowych potrzeb.

W literaturze, dokonujacc analizy zakresu uzasadnionych potrzeb rodziny trafnie, podniesiono, że nie obejmuja one potrzeb zbytkownych ${ }^{14}$. Powstaje za to wątpliwość co do zakresu pojęcia rodziny w rozumieniu analizowanego unormowania, jako że pojęcie to nie jest jednolite na gruncie poszczególnych unormowań k.r.o., a w doktrynie wyróżnia się m.in. tzw. rodzinę małą i rodzinę duża; pojęcie rodziny bywa też niekiedy rozszerzane o istniejące więzi faktyczne ${ }^{15}$. Biorąc pod uwagę funkcje, jakie ma spełniać analizowana regulacja, należałoby dopuścić szersze (tzn. wykraczające poza więzi pokrewieństwa) znaczenie rodziny, korygowane kryterium pozostawania we wspólnym gospodarstwie domowym ${ }^{16}$.

W literaturze wskazano przykłady uzasadnionych potrzeb rodziny, jak m.in.: nabycie przedmiotów urządzenia domowego czy zorganizowanie wakacji itp. ${ }^{17}$ Wyrażony został również pogląd, że chodzi tu tylko o potrzeby wspólne, a nie potrzeby poszczególnych członków rodziny, np. potrzeby rodziców ${ }^{18}$. $\mathrm{Z}$ zastrzeżeniem tym można jednak w pewnym zakresie ostrożnie polemizować. Wydaje się, że środki pochodzące z majątku dziecka powinny służyć przede wszystkim rodzinie jako całości, podnosząc tym samym bezpośrednio stopę życiową dziecka, jako jej członka. Jednakże nie wydaje się całkowicie wykluczone zaspokajanie także indywidualnych uzasadnionych potrzeb pozostałych członków rodziny, jeżeli z uwagi na przynależność tych osób do jednej wspólnoty rodzinnej z dzieckiem i wzajemną współzależność interesów, mogłoby to $\mathrm{w}$ perspektywie wpłynąć pozytywnie na sytuację rodziny ${ }^{19}$, co tym

${ }^{14}$ G. Jędrejek, op. cit., s. 199.

15 Na temat pojęcia rodziny zob. m.in.: A. Szwed, Rodzina-ujęcie socjologiczne i prawne, „Rodzina i Prawo" 2007, nr 3, s. 23-40; E. Wiśniowska, Pojęcie rodziny w ustawodawstwie polskim, „Acta Universitatis Wratislaviensis” 1990, nr 1152, s. 351-360.

16 Podkreśla się, że przepis ten został zredagowany pod kątem rodziny prowadzacej wspólne gospodarstwo - tak J. Marciniak, Treść $i$ sprawowanie opieki nad małoletnim, Warszawa 1975, s. 86. W niektórych wypowiedziach do potrzeb rodziny zalicza się jednak również potrzeby rodzeństwa wychowującego się oddzielnie - tak np. B. Walaszek, Zarys prawa rodzinnego i opiekuńczego, Warszawa 1971, s. 177.

17 J. Ignatowicz, w: System prawa rodzinnego $i$ opiekuńczego, red. J. Piątowski, Wrocław 1985, s. 824

${ }^{18}$ G. Jędrejek, op. cit., s. 199.

${ }_{19} \mathrm{~Np}$. pokrycie kosztów kursu językowego jednego z rodziców, dzięki któremu uzyska on szansę osiągania w przyszłości wyższych zarobków, co z kolei może wpłynąć na podniesienie stopy życiowej rodziny. 
samym pośrednio przełożyłoby się na realizację dobra dziecka. Finansowanie nie mogłoby jednak z pewnością obejmować indywidualnych potrzeb krewnych dziecka spoza wspólnoty domowej, gdyż prowadziłoby to do zachwiania równowagi między interesem dziecka, dla którego dobra (w sferze kształtowania właściwej postawy w zakresie solidarności rodzinnej), ustanowione zostały dyrektywy zawarte w art. 103 k.r.o., a korzyścią beneficjentów - na rzecz tych ostatnich. Tymczasem celem tego unormowania wydają się przede wszystkim względy wychowawcze, a korzyści materialne płynące stąd dla innych osób odgrywają tu wtórną rolę.

Na uwage zasługuje zagadnienie statusu prawnego surogatów nabytych na podstawie art. 103 k.r.o. Przepis ten upoważnia rodziców przede wszystkim do rozporządzania dochodami dziecka w celach konsumpcyjnych - na zaspokojenie bieżących potrzeb dzieci i innych konsumpcyjnych potrzeb rodziny. Nie zawsze jednak wydatkowane środki zostaja zużyte w sposób całkowity; zaspokojenie potrzeb dzieci i rodziny może bowiem polegać na nabywaniu przedmiotów, zwłaszcza rzeczy, które ulegają zużyciu w dłuższym okresie. Jeżeli tego rodzaju przedmioty byłyby nabywane przez rodziców z przeznaczeniem do ściśle osobistego użytku przez wskazaną osobę (np. sprzęt sportowy zakupiony dla rodzeństwa), to można byłoby przyjąć, że z uwagi na cel nabycia wchodzą one do jej majątku, a nie - zgodnie z zasadą surogacji - do majątku dziecka, z którego dochodów zostały zakupione ${ }^{20}$. Z kolei nabyte $\mathrm{z}$ dochodów dziecka przedmioty użytkowe w gospodarstwie domowym (elementy wyposażenia mieszkania, nawet samochód), stają się niepodlegającymi rozliczeniu (o czym szerzej w punkcie IV) nakładami na majątek rodziców ${ }^{21}$.

Należy rozważyć, czy rozporządzając dochodami w trybie art. 103 k.r.o. rodzice mogliby nabyć, w celu zaspokajania potrzeb rodziny, również nieruchomość, zwłaszcza o przeznaczeniu mieszkalnym. Należy zauważyć, że treść art. 103 k.r.o. nie ogranicza rodzaju nabywanych dóbr, ponieważ określa on cele, a nie sposoby realizacji wskazanych celów. Nie należy stąd jednak wyciągać wniosku, że autoryzuje on rodziców do swobodnego nabywania jakichkolwiek potrzebnych w danym momencie rodzinie dóbr. Na zagadnienie to należy spojrzeć szerzej, mając na uwadze skutek, jaki spowodowałoby nabycie nieruchomości z dochodów dziecka. Wydaje się bowiem, że aktywa o charakterze trwałym, przedstawiające znaczną wartość, które oprócz funkcji użytkowej, spełniają również funkcję inwestycyjna, stanowiąc postać lokaty kapitału, nie mogą być traktowane na równi z dobrami o funkcji wyłącznie użytkowej (jak np. urządzenia domowe). Tego rodzaju aktywa muszą zostać umiejscowione w substancji majątku dziecka, za czym przemawia szereg argumentów. Mianowicie, mając na uwadze zasadę proporcjonalności, trzeba stwierdzić, że cel polegajacy na zaspokojeniu potrzeb rodziny zostałby zrealizowany w wystar-

${ }^{20}$ Przy założeniu, że art. 103 k.r.o. nie zmienia co do zasady przynależności dochodów do majątku dziecka, a tylko reguluje zasady zarządu nim. Zob. T. Smyczyński, Prawo rodzinne i opiekuńcze, Warszawa 2009, s. 225.

${ }^{21}$ Odrębnego opracowania wymagałoby rozważenie przynależności tych nakładów do poszczególnych mas majątkowych, w zależności od sytuacji prawnej rodziców. 
czającym stopniu przez możliwość samego tylko korzystania przez rodzinę z nieruchomości należącej do dziecka, a poza ten cel wykraczałoby nabycie jej własności przez rodziców. Za tym kierunkiem wykładni przemawia również zasada dobra dziecka. Poza tym należy mieć na uwadze, że w systemie polskiego prawa rodzinnego został przyjęty model zarządu majątkiem dziecka, a nie model użytkowania tego majątku, w którym pożytki z majątku dziecka przypadałyby rodzicom ${ }^{22}$. Stwierdzenie, że mamy w analizowanym przypadku do czynienia z interwencją w substancję majątku dziecka, polegająca na jej powiększeniu o nieruchomość, pociaga za sobą konsekwencję w postaci konieczności weryfikacji umocowania rodziców do dokonania takiej czynności, jako przekraczającej zakres zwykłego zarządu majątkiem dziecka (art. 101 $\S 3$ k.r.o. $)^{23}$. W tej sytuacji dyrektywy zawarte w art. 103 k.r.o. w związku z zaistniałą potrzebą rodziny nabycia nieruchomości mogą odgrywać rolę argumentu przemawiajacego za udzieleniem przez sąd zezwolenia na dokonanie takiej czynności.

W k.r.o. brak regulacji losów prawnych reszty dochodu, która nie została rozdysponowana na zaspokojenie potrzeb dzieci oraz potrzeb rodziny, a w doktrynie przyjmuje się zgodnie, że powiększa ona majątek dziecka, w myśl reguły, że pożytki rzeczy lub prawa przypadają właścicielowi ${ }^{24}$. Warto byłoby jednak ustalić, w którym momencie dochód zmienia swój status, wtapiając się w substancję majątku, gdyż od tej chwili rodzice nie mogliby nim już obracać na podstawie art. 103 k.r.o., jako że substancja majątku podlega zwiększonej ochronie, a zarząd - kontroli. Trzeba podkreślić, że ustawa nie wprowadza terminu zawitego, w którym dochód musiałby zostać wydatkowany; art. 103 k.r.o. nie konstruuje również po stronie rodziców roszczenia, które mogłoby podlegać przedawnieniu. Brak również podstaw do przyjęcia, że kompetencja rodziców w zakresie dysponowania dochodami, które mają charakter okresowy, miałaby się zakończyć np. wraz z zamknięciem okresu rozliczeniowego, wyznaczającego cykle pobierania pożytków. Status dochodu podlegający reżimowi z art. 103 k.r.o. utrzymuje się zatem aż do czasu ustania władzy rodzicielskiej. Jednocześnie trzeba zastrzec, że rodzice mogliby skapitalizować dochody poprzez połaczenie niewykorzystanej nadwyżki z substancją majątku, przy czym wola dokonania takiej operacji musiałaby co najmniej wynikać z okoliczności i nie powinna być domniemywana. Rodzice mogliby więc postanowić o kapitalizacji dochodu i np. w przypadku lokat pieniężnych zadecydować o kapitalizacji odsetek, które tym samym powiększyłyby substancję majątku dziecka. Mogłoby to nastapić także np. w drodze wykorzystania dochodów na zakup dla dziecka przedmiotów w celu inwestycyjnym (nieruchomość, papiery wartościowe, kosztowności, czy przedmioty kolekcjonerskie), z zastrzeżeniem jednak baczenia na ewentualność przekroczenia w niektórych przypadkach zakresu zwykłego zarządu, co wiązałoby się z koniecznością uzyskania zezwolenia sądu.

${ }^{22}$ Zob. S. Grzybowski, Prawo rodzinne. Zarys wykładu, Warszawa 1980, s. 194. O użytkowaniu ustawowym - A. Sylwestrzak, Użytkowanie. Konstrukcja prawna, Warszawa 2013, s. 113-114.

${ }^{23}$ Szerzej H. Ciepła, Zarzad majatkiem dziecka, „Rodzina i Prawo” 2012, nr 20-21, s. 38-46.

${ }^{24}$ M.in. J. Ignatowicz, w: System..., s. 824. 
W podsumowaniu dokonanej analizy należy zauważyć, że wychowawcza funkcja art. 103 k.r.o. w znaczący sposób ukierunkowuje jego wykładnię, kształtując krag beneficjentów. Treść tego unormowania wzmacnia wniosek, że dobro dziecka nie może być rozumiane jako realizacja egoistycznie pojmowanych interesów, w oderwaniu od interesów wspólnoty rodzinnej, w której się wychowuje ${ }^{25}$. Powyższa konstatacja nie prowadzi jednak do zmiany perspektywy wykładni tego przepisu przez przyjęcie za priorytet dobra innych podmiotów; nadal bowiem analizujemy jego znaczenie pod kątem dobra tego dziecka, którego majątek przynosi dochód. Interesy innych osób są więc realizowane pośrednio - dlatego że przemawia za tym dobro tego dziecka.

\section{ANALIZA KRYTYCZNA OBOWIĄZUJĄCYCH REGULACJI I POSTULATY ZMIAN}

Dla uzyskania pełnej perspektywy skutków art. 103 k.r.o. należałoby rozszerzyć spektrum badań o unormowania dotyczące obowiązku alimentacyjnego, a zwłaszcza art. $133 \S 1$ k.r.o. Przepis ten formułuje obowiązek alimentacyjny rodziców względem dziecka niebędącego jeszcze w stanie utrzymać się samodzielnie, z zastrzeżeniem: „chyba że dochody z majątku dziecka wystarczają na pokrycie kosztów jego utrzymania i wychowania". Przepis ten zwalnia więc rodziców z obowiązku w takim zakresie, w jakim potrzeby dziecka zostaja zaspokojone $\mathrm{z}$ wykorzystaniem jego dochodów ${ }^{26}$. Zasadność takiego zwolnienia nie budzi wątpliwości, ponieważ dochodzi wówczas do samodzielnego (w sensie ekonomicznym) finansowania własnych potrzeb dziecka, co odpowiada leżącemu u podstaw stosunków alimentacyjnych założeniu, że roszczenie alimentacyjne powstaje dopiero wtedy, gdy uprawniony nie może zaspokoić swych potrzeb w ramach własnych możliwości ${ }^{27}$.

Należy zauważyć, że treść tego unormowania dotyczy jednak tylko tego dziecka, z którego majątku płyną dochody i nie ma w nim mowy o analogicznym zwolnieniu wobec rodzeństwa, które również korzysta z tych dochodów. A jednak, pomimo braku wyraźnego zwolnienia, rodzice w istocie i tak będą zwolnie-

25 Wniosek taki wynika również z art. 95 § 3 k.r.o., który pośród dyrektyw wykonywania władzy rodzicielskiej wymienia interes społeczny.

${ }_{26}$ Tak np. J. Ignaczewski, w: idem (red.), Wtadza rodzicielska i kontakty $z$ dzieckiem. Komentarz, Warszawa 2012, s. 138; K. Pietrzykowski, w: idem (idem), Kodeks rodzinny i opiekuńczy. Komentarz, Warszawa 2018, s. 1014. W doktrynie skutek ten określa się jako ustanie obowiązku alimentacyjnego - tak J. Wierciński, w: idem (red.), op. cit., s. 904, bądź jako wygaśnięcie obowiązku alimentacyjnego, K. Kajmowicz, Wygaśnięcie obowiazku alimentacyjnego w aspekcie materialnym i procesowym - zagadnienia wybrane, w: J. Łukasiewicza, I. Ramus (red.), Prawo alimentacyjne. Zagadnienia materialne, t. 2, Toruń 2015, s. 389. Odmiennie E. Budna, Obowiazek alimentacyjny rodziców względem dzieci, „Nowe Prawo” 1990, nr 7-9, s. 65-70, która uważa, że osiaganie przez dziecko dochodów nie zwalnia rodziców z obowiązku alimentacyjnego, a jedynie wpływa na zakres tego obowiązku.

27 Zob. np. J. Gwiazdomorski, Treść i zakres obowiazku alimentacyjnego między krewnymi, „Państwo i Prawo” 1954, z. 9, s. 248-249. 
ni - przynajmniej częściowo - od obowiązku alimentacyjnego wobec pozostałych dzieci, ze względu na to, że na skutek konsumowania dochodów dochodzi do zaspokojenia (w całości lub części) potrzeb rodzeństwa uposażonego dziecka, co z kolei wpływa na oznaczenie zakresu świadczeń alimentacyjnych rodziców ${ }^{28}$. Zakres ten zależy, w myśl art. $135 \S 1$ k.r.o., m.in. od usprawiedliwionych potrzeb uprawnionego, a zatem jeśli potrzeby rodzeństwa zostały już zaspokojone - roszczenie alimentacyjne wobec rodziców nie aktualizuje się wcale bądź zaktualizuje się jedynie uzupełniająco - w zakresie pozostających jeszcze do zaspokojenia potrzeb. Świadczenia alimentacyjne jawią się więc w świetle takiej regulacji jako subsydiarne źródło finansowania potrzeb rodzeństwa, ponieważ podstawowym źródłem stają się dochody z majątku brata/siostry.

Wynikająca z przytoczonych unormowań kolejność źródeł zaspokajania potrzeb rodzeństwa budzi istotne zastrzeżenia. Negatywne skutki aktualnych unormowań uwypuklają się zwłaszcza w przypadku rodzin zamożnych, w których dobrze sytuowani rodzice, majaccy zdolność do utrzymania dzieci na wysokim poziomie materialnym, wydatkowaliby dochody z majattku jednego z dzieci na zaspokojenie potrzeb także jego rodzeństwa, a w konsekwencji doznawaliby ulgi w wykonywaniu obowiązków alimentacyjnych, kosztem dochodów z majątku jednego z dzieci. W istocie dochodziłoby wówczas do przerzucenia ciężaru alimentacji z rodziców na jedno z dzieci, wobec czego stawałoby się ono pierwszym w kolejności podmiotem obciążonym zaspokajaniem potrzeb swojego rodzeństwa.

Oczywiście w ramach dysponowania dochodem dziecka na podstawie art. 103 k.r.o. nie mamy do czynienia ze spełnianiem świadczeń stricte alimentacyjnych, lecz z wykonywaniem zarządu majątkiem dziecka, ale ponieważ tego rodzaju dyspozycje wywołują skutki bezpośrednio w zakresie alimentacji, ostateczny efekt jest podobny do tego, jak gdyby dziecko zostało ulokowane na pierwszej pozycji jako dłużnik alimentacyjny swego rodzeństwa, a rodzice (wstępni) dopiero w następnej kolejności. Rozwiązanie takie jest niespójne aksjologicznie z treścią art. 129 k.r.o., który określa kolejność obowiązku alimentacyjnego w ten sposób, że lokuje rodzeństwo jako zobowiązane dopiero w ostatniej kolejności, jak również z art. 134 k.r.o., dodatkowo osłabiajacym obowiąek alimentacyjny między rodzeństwem przez uprawnienie do uchylenia się od świadczeń we wskazanych okolicznościach. Z unormowań tych wyczytać można bowiem ogólniejszy zamysł ustawodawcy, by rodzeństwo zostało obciążone obowiązkiem alimentacyjnym dopiero w ostateczności. Dodatkowo można w dyrektywach wyrażonych w art. 103 k.r.o. upatrywać nieuzasadniony aksjologicznie przywilej dla rodziców, co uwidacznia się w sytuacji, gdy zarówno majątki rodziców, jak i majątek dziecka przynosiłyby dochód - wówczas rodzice mogliby zaoszczędzić wydatków, kumulując tym samym własne dochody kosztem dochodów z majątku dziecka, które nie byłyby akumulowane,

28 Zob. M. Lech-Chełmińska, V. Przybyła, Kodeks rodzinny i opiekuńczy, Warszawa 2006, s. 324; E. Wojtaszek-Mik, Wygaśnięcie obowiazku alimentacyjnego rodziców wobec dzieci, w: M. Kosek, J. Słyka (red.), W trosce o rodzinę. Księga pamiatkowa ku czci Profesor Wandy Stojanowskiej, Warszawa 2008, s. 586. 
ponieważ byłyby obracane na utrzymanie rodzeństwa. Dziecko, jako podmiot słabszy, zasługuje w rodzinie na szczególną ochronę, dlatego przedstawiony stan rzeczy, który może stwarzać zagrożenie dla jego dobra, trzeba ocenić jako wadliwość obowiąujących unormowań.

Podobne zarzuty można sformułować pod adresem zawartej w art. 103 k.r.o. dyrektywy obracania dochodu na inne uzasadnione potrzeby rodziny. Zagrożenie dla interesów dziecka mogłoby powstać wtedy, gdyby potrzeby rodziny nie były zaspokajane ze środków pochodzących od dobrze sytuowanych rodziców, lecz z dochodów z majątku dziecka. Należy przy tym zauważyć, że jeżeli rodzice pozostają w związku małżeńskim, zobowiązani są oni na mocy art. 27 k.r.o. do przyczyniania się do zaspokajania potrzeb rodziny. Jednakże gdyby potrzeby te zostały zaspokojone częściowo z majątku dziecka - spowoduje to automatyczne zmniejszenie obowiązu z art. 27 k.r.o., ponieważ mniej pozostanie potrzeb do zaspokojenia. Tymczasem pożądana kolejność byłaby odwrotna - jako pierwsi do zaspokajania potrzeb rodziny powinni być powołani małżonkowie, a dochód dziecka powinien służyć im tylko wtedy, gdyby nie mogli tych potrzeb zaspokoić własnymi siłami. Gdyby rodzice pozostawali w konkubinacie, brak analogicznego do art. 27 k.r.o. obowiązku o charakterze prawnym, jednak i tu można mówić o wynikającym z zasad współżycia społecznego obowiązku wsparcia materialnego, którego realizacja powinna mieć pierwszeństwo przed ewentualna konsumpcją dochodów z majątku dziecka.

Dalsze zastrzeżenia budzi zastosowanie w art. 103 k.r.o. kategorii obowiązku, wyznaczającej sytuację rodziców w zakresie zarządu dochodami dziecka. Wynikać stąd może bowiem wniosek, że obracanie dochodem jest powinnościa rodziców w każdym przypadku, gdy tylko dochód jest osiagany, co prowadzi do ogólniejszego stwierdzenia, że rozporządzanie dochodem w celach wskazanych w art. 103 k.r.o. jest obligatoryjne ${ }^{29}$, a zaniechanie takich rozporządzeń stanowi uchybienie. Twierdzenie takie byłoby w pełni uprawnione w przypadku rodzin o niskiej, a nawet przeciętnej stopie życiowej, w których skorzystanie z dochodów, jakie przynosi majątek dziecka, skutkuje wyraźnym podniesieniem poziomu życia rodziny. Konsumowanie dochodów dziecka jest wówczas zjawiskiem pożądanym. Jednakże w rodzinach o wysokiej stopie materialnej korzystanie z dochodów z majątku dziecka, jak już wcześniej wykazano, mogłoby prowadzić do uprzywilejowania majątkowego rodziców, z poświęceniem interesów dziecka.

Przeprowadzona dotąd analiza wskazuje na to, że dyrektywy zawarte w art. 103 k.r.o. prowadzą do pożądanych konsekwencji społecznych tylko w pewnym zakresie, mianowicie w odniesieniu do zaspokajania potrzeb dziecka, któremu przysługuje majątek, natomiast w odniesieniu do pozostałych wyliczonych tam celów (potrzeby rodzeństwa, inne uzasadnione potrzeby rodziny) - tylko pod warunkiem, gdyby rodzice nie byli w stanie zaspokoić tych potrzeb własnymi siłami. Powstajace na gruncie tego unormowania, wy-

${ }^{29}$ Czyli jedynie działanie („obracanie”) byłoby w tym ujęciu przejawem starannego zarządu majątkiem dziecka (art. $101 \S 1$ k.r.o.). W doktrynie art. 103 k.r.o. jest uważany za rozwinięcie dyrektywy zawartej w art. 101 § 1 k.r.o. - T. Smyczyński, Obowiqzek alimentacyjny rodziców względem dziecka a polityka socjalna państwa, Wrocław 1978, s. 64. 
kazane wyżej zagrożenia należałoby, de lege lata, minimalizować przy zastosowaniu wykładni funkcjonalnej, dokonując interpretacji art. 103 k.r.o. przez pryzmat dobra dziecka, jako zasługującego na szczególną ochronę podmiotu słabszego, skąd można byłoby podjąć próbę wywodzenia ograniczeń w dysponowaniu jego dochodem w sytuacji, kiedy z uwagi na poziom majątkowy rodziców dyspozycje takie nie byłyby konieczne. Brzmienie unormowań prawnych, choć możliwe do skorygowania w pewnym zakresie na drodze umiejętnej wykładni, nie powinno jednak dawać furtki do naruszania tak istotnej wartości, jaka stanowi dobro dziecka, dlatego w dalszej perspektywie należałoby postulować nowelizację art. 103 k.r.o. W jej ramach należałoby rozważyć celowość zmiany kategorii powinności rodziców na kategorię uprawnienia, którego wykonywanie byłoby jednak ukierunkowane w określonych przez ustawodawcę celach. Rodzice dobrze sytuowani mogliby tym samym alimentować dziecko ze swoich własnych środków, akumulując dochody z majątku dziecka jako jego wyposażenie na przyszłość, gdyż wydatkowanie tych dochodów na utrzymanie dziecka nie byłoby ich obowiązkiem. Z kolei w rodzinach uboższych, w których sięgnięcie po dochody dziecka wpłynęłoby znacząco na poziom życia rodziny, skorzystanie z tego uprawnienia, z uwagi na ogólne dyrektywy powinnościowe zawarte w art. 95 k.r.o. - i tak stanowiłoby jednocześnie ich obowiąek.

Ponadto nowelizacja powinna zmierzać do wprowadzenia dodatkowych przesłanek ograniczających dostęp do wydatkowania dochodów na potrzeby rodzeństwa oraz inne uzasadnione potrzeby rodziny. Mianowicie w pierwszej kolejności byłyby pokrywane, jak dotąd, z przychodów koszty zarządu majątkiem dziecka. W drugiej kolejności realizowane byłyby potrzeby dziecka, któremu majątek przysługuje. Natomiast pokrywanie potrzeb rodzeństwa wychowującego się wspólnie, a w dalszej kolejności innych uzasadnionych potrzeb rodziny powinno zostać obwarowane zastrzeżeniem subsydiarności względem istniejących obowiązków alimentacyjnych. Potrzeby te mogłyby więc być zaspokajane z dochodów z majątku dziecka tylko wówczas, gdyby nie udało się pokryć wszystkich uzasadnionych potrzeb w ramach wykonywania obowiązków alimentacyjnych.

\section{INGERENCJA SĄDU W ZARZĄD DOCHODAMI DZIECKA ORAZ PROBLEMATYKA SANKCJI ZA NARUSZENIE ART. 103 K.R.O.}

Z przepisów k.r.o. o zarządzie majątkiem dziecka wynika, że kontrola poczynań rodziców w zakresie gospodarowania dochodem z tego majątku podlega w pewnym zakresie szczególnym unormowaniom. Mianowicie w art. 104 $\S 2$ k.r.o., na którego podstawie sąd opiekuńczy może w uzasadnionych wypadkach ustalić wartość rozporządzeń dotyczących ruchomości, pieniędzy i papierów wartościowych, których dziecko lub rodzice mogą dokonywać każdego roku bez zezwolenia sądu opiekuńczego, zastrzega się uwzględnienie art. 103 k.r.o. Zastrzeżenie to można rozumieć na dwa sposoby; po pierwsze - jako wyjęcie spod kompetencji sądu możliwości limitowania obrotu dochodami z majątku dziecka. W myśl tej koncepcji kompetencja rodziców do obracania dochodem 
nie podlegałaby w tym trybie ograniczeniu - i to bez względu na wysokość osiaganego dochodu, ponieważ rozmiar wydatkowanych kwot wyznaczają każdorazowo istniejace potrzeby w zakresie utrzymania i wychowania rodzeństwa oraz uzasadnione potrzeby rodziny. Możliwe jest również takie rozumienie art. $104 \S 2$ k.r.o. in fine, które nie wyklucza ingerencji sądowej w zakresie ustalenia wartości rozporządzeń, a „zastrzeżenie art. 103 k.r.o.” oznacza, że sąd, określając dopuszczalny limit obrotu dochodami, powinien uwzględnić oznaczone w art. 103 k.r.o. cele, którym dochody te powinny służyć ${ }^{30}$. Ograniczenie powinno być zatem ustalone na takim poziomie, który by umożliwiał, w ramach limitu dopuszczalnych rozporządzeń, zaspokajanie potrzeb dzieci i uzasadnionych potrzeb rodziny. Należy uznać, że z uwagi na dobro dziecka, będącego podmiotem majątku, prawidłowy jest ten drugi, zawężający swobodę rodziców, kierunek wykładni. Stwarzanie po stronie rodziców sfery nienaruszalnych kompetencji nie znajduje umocowania w ramach całokształtu przepisów o władzy rodzicielskiej, a zwłaszcza przepisów o sądowej ingerencji w tę władzę. Sąd opiekuńczy może więc nie tylko, na podstawie art. $104 \S 2$ k.r.o., ograniczyć wartość samodzielnych rozporządzeń dochodami z majątku dziecka, lecz również, jeżeli ziściła się przesłanka zagrożenia jego dobra (np. gdyby rodzice wydatkowali dochód na finansowanie niepożądanych, z punktu wiedzenia dobra dziecka, celów), ograniczyć władzę rodzicielską w odniesieniu do dochodów z majątku na podstawie art. 109 k.r.o., np. przez powierzenie zarządu ustanowionemu w tym celu kuratorowi ${ }^{31}$. Przejęcie przez kuratora zarządu dochodami powinno, jak się wydaje, wiązać się z obowiązkiem kuratora realizacji określonych w art. 103 k.r.o. celów, którym ten dochód ma służyć.

Unormowaniem mającym wpływ na zakres sankcji za naruszenie przez rodziców dyrektyw z art. 103 k.r.o. jest art. 105 zd. 3 k.r.o., zgodnie z którym przysługujące dziecku lub jego przedstawicielowi ustawowemu roszczenie o złożenie rachunku z zarządu nie może dotyczyć dochodów z majątku pobranych w czasie wykonywania władzy rodzicielskiej. W doktrynie wywodzi się stąd brak obowiązku rozliczenia się przez rodziców z pobranych dochodów ${ }^{32}$. Idąc tym tropem, można stwierdzić, że rodzice nie ponoszą wobec dziecka odpowiedzialności odszkodowawczej za nienależyte sprawowanie zarządu dochodami pobranymi z majątku; odpowiedzialność ta ogranicza się bowiem do substancji majątku. Zagadnienie to warto nieco doprecyzować. Z wyłączenia roszczenia o rachunek z zarządu dochodami można wnosić, co najwyżej, o wyłączeniu wobec dziecka odpowiedzialności za uszczerbek polegający na utracie pobranych z jego majątku dochodów, co pozostaje spójne z kompetencją rodziców do ich dosyć swobodnego (pomimo kierunków wskazanych w art. 103 k.r.o.) wydatkowania. Jeżeli jednak, dokonując obrotu dochodami, rodzice wyrządzili szkodę w substancji majątku dziecka (np. w drodze niestarannych inwestycji) bądź na osobie dziecka (np. przeznaczając dochód na zakup dla dziecka używek), ponoszą

${ }^{30}$ Zob. T. Sokołowski, w: H. Dolecki, T. Sokołowski (red.), op. cit., s. 717.

${ }^{31}$ Zob. H. Ciepła, w: K. Piasecki (red.), Kodeks rodzinny i opiekuńczy. Komentarz, Warszawa 2011, s. 784 i M. Grochowski, w: K. Osajda (red.), op. cit., s. 1274; S. Szer, Prawo rodzinne, Warszawa 1966, s. 275.

${ }^{32}$ J. Gajda, w: K. Pietrzykowski (red.), op. cit., s. 829. 
odpowiedzialność na zasadach ogólnych, a wykorzystanie dochodów dziecka podczas wyrządzania mu szkody nie mogłoby być traktowane jako okoliczność zwalniająca - ponieważ w tym przypadku dobrem podlegających ochronie nie jest dochód jako taki, lecz osoba dziecka bądź substancja jego majątku.

$$
* * *
$$

Podsumowując rozważania dotyczące zarządu dochodami dziecka, należy zauważyć, że art. 103 k.r.o. obowiązuje bez zmian od czasu wejścia w życie k.r.o., a dostosowany on został odpowiednio do realiów ustroju socjalistycznego, kiedy to podkreślano, że sytuacja, w której majątek dziecka byłby źródłem dochodów, jest zjawiskiem rzadkim ${ }^{33}$. Obecnie, mając na uwadze zmianę realiów ekonomicznych społeczeństwa, należy założyć, że dzieci moga znacznie częściej stawać się podmiotami majątków (np. w drodze dziedziczenia) i osiagać z tychże majątków dochody ${ }^{34}$, a zjawisko takie może mieć miejsce również w rodzinach o wysokiej materialnej stopie życiowej, w których sięganie do dochodów dziecka w celu alimentowania rodzeństwa oraz zaspokajania innych potrzeb rodziny nie wydaje się pożądane. Pojawia się zatem potrzeba ograniczenia kompetencji rodziców do obracania dochodami dziecka, aby nie dochodziło do faktycznego wyprzedzenia rodziców w alimentowaniu dzieci przez rodzeństwo. Majac te zagrożenia na uwadze, przedstawiono zatem, de lege lata, szereg postulatów w zakresie pożądanego kierunku wykładni analizowanego przepisu, jak również propozycję jego nowelizacji, zmierzająca do przywrócenia właściwej proporcji obciążeń materialnych kosztów zaspokajania potrzeb rodziny.

\author{
dr hab. Anna Sylwestrzak \\ Profesor Uniwersytetu Gdańskiego \\ annasylwestrzak@prawo.ug.edu.pl \\ https://orcid.org/0000-0001-8346-1926
}

\title{
MANAGEMENT OF THE INCOME FROM THE CHILD'S ASSETS
}

\author{
Summary
}

The gradual increase in the affluence of the Polish society makes it increasingly common for a child to acquire wealth that generates income. The rules of the management of the income from the child's assets have therefore increased in importance over time. The article contains a detailed analysis of Article 103 of the Polish Family and Guardianship Code, according to which pure income from the child's property should be primarily used for the maintenance and upbringing of the child and its siblings who are raised together with the child, and as a surplus for other justified needs of the family. This provision has an educational function and strengthens the sense of family solidarity. However, in families with a high standard of living, it may pose a threat of the actual shifting of the burden of maintenance from parents to a beneficiary child. This would be contrary to the maintenance obligation provided by law under which siblings are the last to be obliged to provide maintenance. This risk can be reduced by an interpretation that gives priority to maintenance obligations over meeting the needs of siblings and the family at the expense of the child's income. It would also be desirable to amend Article 103 of the Family and Guardianship Code by introducing restrictions on the use of the income from the child's property.

33 Zob. np. T. Smyczyński, Obowiqzek..., s. 64, przyp. 70.

${ }_{34}$ A. Bodył-Szymala, Gdy z rachunku dziecka rodzic wypłaca jego pieniadze, „Rzeczpospolita” z 23 maja 2008 r., dział „Prawo”. 